\title{
„Társadalmunkban a sikert a nyilvánosság iktatja törvénybe", avagy a vidéki színésznő siker- és karriermodellje
}

\author{
BALUJA PETRA ${ }^{1}$
}

\begin{abstract}
ABSZTRAKT
Tanulmányomban arra keresem a választ, hogy kimutathatóak-e különbségek abban, ahogy a színésznők és színészek definiálják karrierjüket, sikereiket? Mit jelent a vidéki színház színészeinek sikere? Ennek kifejtésére több kortárs, sikerre irányuló elemzést ismertetek, amelyek közül Deaton-Kahnemann és Barabási föbb elméleteire támaszkodom. Ezt követően a kutatásom módszertanát mutatom be, majd Bourdieu mezőelmélete alapján a kőszínház munkaszervezetének értelmezése kap nagyobb hangsúlyt. Végül a szervezetszociológiai kontextusba ágyazva írom le, hogy a színmüvészek hogyan értelmezik a sikert és a karriert, illetve mindezek alapján tipizálom habitusaikat.
\end{abstract}

KULCSSZAVAK: vidéki színház, szervezet, siker, karrier

\section{ABSTRACT}

„In our society publicity ratify the success”. Success and career model of rural theater's artists

This study aims to answer the question of how actors and actresses define their own success and carreer. What does succes mean to an artist in rural theater? The study primaly discusses some contemporary analyses of sucess, amongst them I am using Deaton-Kahnemann's and Barabási's theories. I am also presenting the metodology of my research and later I show rural theatre's organization based on Bourdieu's theory. Finally I describe the definition of success and career of the actors and actresses embedded in an organizational context which helps to understand their tipical habits.

KEYWORDS: rural theatre, organization, success, career

${ }^{1}$ Debreceni Egyetem Humán Tudományok Doktori Iskola Szociológia és Társadalompolitika Doktori Program, e-mail: balujapetra@gmail.com 


\section{KÖZELKÉP}

\section{Bevezetés}

A színházi világ köznapi megítéléséhez számos feltevés kapcsolódik, mint például a „normáktól való eltérés”, az ünnepélyesség, a reflektorfényben élő művészek rendhagyó életmódja, akik teljesítménye, sikeressége azonnali visszajelzést kap a szakmai kritikától, a sajtótól és a közönségtől.

Jelen tanulmány egy kiterjedt kutatás része, amelyben nagyobb perspektívában vizsgálom a témát (a vidéki színház szervezeti struktúrája ad keretet a színésznők és színészek közötti nemi egyenlőtlenségek leírásához), de jelen írás egyetlen kutatási kérdésre fókuszál. Arra a kérdésre keresem a választ, hogy kimutathatóak-e különbségek abban, ahogy a színésznők és színészek definiálják karrierjüket, sikereiket? Mikor és mitől elégedettek a sikereikkel? Mit jelent a vidéki színház színészeinek sikere?

Magyarország két vidéki repertoárszínházában történt az adatfelvétel a félig strukturált interjú módszerével. Vidéki repertoárszínház kifejezés alatt a fővárosi színházvilágon kívüli, nem budapesti kőszínházi intézményeket értem. A vidékiség egyfajta egyenlőtlenségi keretet nyújt a nemi egyenlőtlenségek leírásához. Kevés elemzés született a vidéki kőszínházak működésével kapcsolatban, kutatásom során azt tapasztaltam, hogy a fővárosi és a vidéki színházi múködés között jelentős eltérések vannak.

A szöveg első részében röviden ismertetek néhány kortárs sikerre irányuló elemzést, melyek részletezik, hogy milyen szempontból közelítik meg a fogalmat és ezeknek segítségével mutatom be saját értelmezési keretemet is. A sikerre és a karrierre Deaton-Kahnemann munkájára támaszkodva szubjektív változóként tekintek. A szubjektív változók bevonásával árnyaltabban értelmezhetők a nemi különbségek. Ezt követően a vizsgálatom módszertanát részletezem (kutatás helyszíne, interjúalanyok, mintavétel), majd a vidékiség és a kőszínház munkaszervezetének értelmezése kap nagyobb hangsúlyt. A vidéki, kőszínházi szervezet nyújt értelmezési keretet a benne dolgozó színésznők és színészek mikroviszonyaiban leírható egyenlőtlenségeknek. A szervezeti struktúrát mikro-, mezo- és makroszinten értelmezem, jelezve ezzel komplex működését. Itt fokozatosan haladunk a kőszínház szerveződési szintjein át a konkrét személyekig, a színésznőkig és színészekig, akik a struktúra részei. Siker és karrier fogalmukra hatással vannak a szerveződési szintek és az általuk generált feszültségek.

Végül a szervezet szociológiai kontextusába ágyazva írom le, hogy a színmúvészek hogyan értelmezik a sikert, elégedettséget és a karriert, mindezek alapján tipizálom habitusaikat. A nemek között leírható hátrányokon túl felhívom a figyelmet az előnyökre is, az interjús idézetek segítségével. 


\section{KÖZELKÉP}

\section{A siker értelmezése a kortárs elemzésekben}

Deaton értelmezésében a siker és sikeresség a haladást, a fejlődést, az életszínvonal emelkedését, az egyéni szabadságot és a lehetőségekhez való hozzáférést jelenti. Ezenfelül a boldogság és az élettel való elégedettség fogalmát szigorúan elkülöníti egymástól. Véleménye szerint a kettő nem azonos, ugyanis amíg a boldogságérzés az érzelmi tapasztaláson, addig az elégedettség megfontoláson, racionalitáson alapszik. Az elégedettséget a világ országaira lebontva (makroszinten) a jövedelem és egészségi állapot korrelációjában vizsgálta. Legfőbb következtetése, hogy ahol magas az átlagjövedelem (GDP), az élettel való elégedettség és az egészségügy színvonala, ott magas az élettel való elégedettség. Ezzel szemben, ahol kisebb a jövedelem és jellemzően szegénység van, ott az élettel való elégedettség is lényegesen alacsonyabb (első Dánia és a skandináv országok, sereghajtó Afganisztán). Deaton kihangsúlyozza, hogy az élettel való elégedettség és a jólét nehezen mérhető. Kizárólag öszszetett dimenziókból közelíthető meg, amibe beletartozik a pénz, az egészség, az oktatás, a társadalmi részvétel, a szabadság, a lehetőségekhez való hozzáférés és az egyéni autonómia. Deaton a jólétet elsősorban a jövedelemmel és az egészség elemeivel való korrelációban vizsgálja (Deaton 2013).

A boldogságkutatások témájában született Angus Deaton és Daniel Kahneman 2010-ben megjelent High income improves evaluation of life but not emotional well-being című munkája. 450000 fő körében végezték survey kutatásukat a világ országaiban 2008 és 2009 között, amit a Gallup Organization in the Gallup-Healthwasy Well Bein Indexére (GHWBI) alapoztak. Elkülönítették egymástól a szubjektív jóllét két kategóriáját. Az egyik az úgynevezett „emotional well-being”, vagyis az érzelmi jóllét, szubjektív boldogságérzet volt, ami többek között azt jelöli, amikor az egyént öröm, bánat éri, szomorú vagy éppen dühös. A másik kategória a „life evaluation", vagyis az élettel való elégedettség volt. A válaszadó alanyoktól azt kérték, hogy fogalmazzák meg gondolataikat arról, hogyan racionalizálják saját életüket és mennyire elégedettek vele. Végül a vizsgálatuk kimutatta, hogy a legtöbb interjúalany szerint pénzen lehetséges bizonyos fokú „élettel való elégedettséget” vásárolni, ellenben boldogságot nem. Ezenfelül megállapították, hogy alacsony jövedelem esetén kimutatható egy alacsony élettel való elégedettség és alacsony érzelmi jóllét (vagyis boldogság) is. Ugyanakkor, annak ellenére, hogy a boldogsághoz alapvetően nem szükséges még több pénz, anyagi forrás, ám a relatíve alacsony jövedelmi helyzethez, ahogy fogalmaznak „emocionális fájdalomérzet” társulhat (Deaton-Kahnemann 2010).

Az OECD hasonló témakörben készített elemzése a Better Life Index - Country Reports volt. A Better Life Index egy összetett mérőszám, amely 11 jólléti (well-being) dimenzióban² 36 országot vizsgált meg. A felmérés 88000 fővel készült 2011-2016

${ }^{2}$ Otthon és lakhatás, jövedelem, munka, közösség, oktatás, környezet, társadalmi szerepvállalás/ részvétel, egészség, élettel való elégedettség, biztonság, munka és család egyensúlya. 


\section{KÖZELKÉP}

között. Ennek alapján az OECD az élettel való elégedettséghez társította a pihenést, a büszkeséget, az örömteli történéseket, tehát a felmérés nem szigorúan különíti el az elégedettséget és a boldogságot, ahogy azt Deaton tette (OECD 2017).

Számos hasonló kutatás arra jut (idézi Balestra - Boarini - Tosetto 2018), hogy a szubjektív boldogság, az élettel való elégedettség és az egészségi állapot egyre inkább meghatározóak és első helyen szerepelnek a válaszadók rangsorában. Alder és Dolan 2008-as elemzésükben 72 hallgatót vizsgáltak meg Londonban és Philadelphiában, ahol 16 jóléti dimenziót rangsoroltak, amelyek közül az első az egészség, a második pedig a boldogság dimenziója volt. Benjamin és munkatársai 2014-es munkájukban viszont már 136 jóléti dimenziót soroltak fel, ahol a fentiek mellett első helyeken szerepelt még a szabadság és a másik ember jólléte iránti figyelem is. Összesen 4600 embert kérdeztek meg, hogy ezeket a dimenziókat rangsorolják. A vizsgálat eredményének sorrendje a következő: 1. szubjektív jólét, 2. élettel való elégedettség, 3. egészségi állapot, 4. családi, rokoni kapcsolatok. Decancq és Watson 2014-es vizsgálatukban eltérő eredményekre jutottak a két nemre vonatkozóan Belgiumban és Kolumbiában. A megkérdezett belga férfiak számára kiemelten fontosak az anyagi feltételek, az egészségi állapot sokkal kevésbé. Ellenben a belga nőknél ez fordítottan igaz. Kolumbiában azonban a férfiaknak sokkal inkább fontos az egészség és jövedelem, mint a nőknek, de az anyagi feltételek szempontjából nincs szignifikáns különbség a nemek között (Balestra - Boarini - Tosetto 2018).

A siker az élettel való elégedettséggel rokonítható fogalom. Multidimenzionális definíció, amely függ a társadalom értékpreferenciáitól, a sikerrel kapcsolatos ideológiáktól és az egyén személyes attitűdjétől. Ezenfelül a siker különbözőképpen, más-más formában jelenik meg a különböző területeken is, például eltérőek a sportolói vagy művészi sikeresség kritériumai (Váriné 1999).

A hazai sikerkutatások közül az egyik legjelentősebb a hálózatkutató Barabási Albert-László $A$ képlet címủ műve. Kötetében öt pontban foglalta össze a siker törvényeit, illetve a siker és teljesítmény dimenzióit is összekapcsolta. Az 1. törvény, hogy a teljesítmény vonzza a sikert, de ha a teljesítmény nem mérhetô, a sikert a hálózatok hozzák meg. Ezt azzal magyarázza, hogy a sportteljesítmény mérése a művészeti alkotásokhoz viszonyítva könnyű. A művészi teljesítmény értékét, sikerességét a galériák, kurátorok, külső megítélők adják meg. A 2. törvény, hogy a teljesítmény korlátos, a siker korlátlan, vagyis a teljesítménykülönbség nehezen mérhető, jó megítéléssel azonban felértékelődhet. A 3., az alkalmasság és korábbi sikerek szorzata előirányozza a jövőbeni siker lehetőségét, vagyis aki korábban sikeres volt, még sikeresebbé válhat. A sikerességek „elosztásában” a teljesítmény különbsége is nehezen mérhető, s abban látta a különbséget, hogy az egyik sportoló sikeresebb megítéléséhez hozzájárul, hogy mennyire népszerüsítik, mennyit van előtérben. A 4. törvény szerint a sikerességet csapatmunka teljesítményével lehet elérni, az ebből adódó sikerességet azonban egyetlen ember élheti meg. Az 5. törvény, hogy ha az 


\section{KÖZELKÉP}

egyén elég kitartó, a sikerességet bármilyen életkorban elérheti, mert a kreativitásnak nincs kapcsolata az életkorral (Barabási 2018).

A továbbiakban azt is vizsgálom, hogy a fenti törvények milyen módon jelennek meg a vidéki színművészekkel készített interjúkban. Milyen eltérések és hasonlóságok mutathatók ki a fentiekhez képest a színészek és színésznők siker-, sikeresség- és boldogságdefinícióját illetően. Ahogy a bevezetőben említettem, Barabási eredményei mellett még Deaton-Kahnemann kutatására építve vizsgálom a siker és karrier szubjektív változóit. De amíg az említett szerzők elsősorban makroszinten, országos lebontásban vizsgálták a sikert és sikerességet, addig saját elemzésemben a mikroszintű színészi sikerességre fókuszálok egy speciális közegben, a vidéki kőszínházi szervezetben, ennek során igyekszem képet adni a vidéki színművészek sajátos karriermodelljéről.

\section{A kutatás módszerei}

Tanulmányomban arra a kérdésre keresem a választ, hogy kimutathatóak-e különbségek abban, ahogy a színésznők és színészek definiálják karrierjüket, sikereiket? Mikor és mitől elégedettek a sikereikkel? Mit jelent a vidéki színház színészeinek sikere?

A félig strukturált interjú módszerével dolgoztam, és az elemzés négy kutatási dimenzió mentén zajlott. Az első dimenzióban az interjúalanyok pályaszocializációját mértem fel, a második dimenzióban a jelenlegi családi életükről, családi állapotukról, a harmadik dimenzióban az általuk tapasztalt és foglalkozásukkal szembeni sztereotípiákról, előítéletekről, a negyedik dimenzióban a színházról mint munkaszervezetről, valamint az interjúalanyok saját siker- és karrierdefiníciójáról kérdeztem őket.

Magyarország két vidéki repertoárszínházában végeztem az adatfelvételt. Vidéki repertoárszínház kifejezés alatt a fővárosi színházvilágon kívüli, nem budapesti kőszínházi intézményeket értem. A terep kiválasztásánál motivációt jelentett, hogy kevés elemzés született a vidéki kőszínházak működéséről, kutatásom alatt azt tapasztaltam, hogy a fővárosi és a vidéki színházi működés között jelentős különbségek állnak fenn. A vidékiség egyfajta egyenlőtlenségi keretet nyújt a benne lévő nemi egyenlőtlenségek leírásához.

2016-tól kezdődően a kutatásban kényelmi mintavételre került sor. Az interjúalanyok kiválasztásánál hólabda módszert alkalmaztam és legfőbb szempont az volt, hogy vidéki kőszínháznál foglalkoztatott prózai színésznők és színészek legyenek, akik már legalább egy évadot töltöttek az anyaszínháznál. A vidéki színház intézményébe civilként nehéz bejutni, éppen ezért kezdetben a színházak művészeti vezetésével és igazgatójával vettem fel a kapcsolatot. 


\section{KÖZELKÉP}

Az interjúalanyaim két, hazai vidéki kőszínházban dolgozó prózai színészek és színésznők voltak. A félig strukturált interjú módszerével, diktafonnal rögzítve 34 fővel készült anonim beszélgetés. Ezek időtartama átlagosan 1,5-2 órás volt. A hangfájlokból szó szerinti átiratokat készítettem. A nemi megoszlást tekintve 21 nő és 13 férfi volt az interjúalanyok között. Életkoruk széles skálát fedett le, 24 és 77 év közöttiek voltak. Színészképesítést a következő intézményekben szereztek: Budapesti Színház- és Filmművészeti Egyetem, Kaposvári Egyetem, Marosvásárhelyi Művészeti Egyetem, Shakespeare Múvészeti Akadémia, Gór-Nagy Mária Színitanoda, Keleti István Múvészeti Főiskola, Regionális Színházművészetért Alapítványi Színiiskola.

A vidéki színház szervezeti kultúrájának leírásához dokumentumelemzést is végeztem, a rendelkezésre álló, publikus anyagokból (alapító okiratok, SZMSZ, szervezeti ábrák). Az alanyok szubjektív válaszait szakértői véleményként kezeltem. A kőszínházi szervezetet három szintű megközelítésben írom le: mikro (vidékiség), mezo (színház mint alrendszer), és makro (színház mint mező), jelezvén, hogy ezek a szintek egymásba kapcsolódva működnek, és erős befolyást gyakorolnak a művészek siker és karrier fogalmaira.

A tanulmány logikai struktúrájában fokozatosan haladunk a kőszínház szerveződési szintjein át a konkrét személyekig, a színésznőkig és színészekig, akik a struktúra részei. Siker és karrier fogalmukra hatással vannak a szerveződési szintek. Az első, vagyis a mikroszintű szerveződési szint leírásához, a szakirodalmi és empirikus forrás hiányossága miatt az alanyoktól vett gondolatokra támaszkodom. Ezt követi a mezoszintű (amit színházi alrendszernek nevezek), majd a makroszintű szerveződési szint (amit színházi mezőnek nevezek el). A szerveződési szintek legfőbb jellemzőit a későbbiekben az 1. számú táblázat foglalja majd össze, illetve rámutat a szinteken létrejövő konfliktusokra, melyeket a színésznők és a színészek nehézségként, egyenlőtlenségként érzékelnek.

\section{A „vidékiség” mint a kőszínházi szervezet mikroszintje}

A kutatásom helyszínei magyarországi, vidéki repertoárszínházak voltak. A vidéki színházak kiesnek a színházi szakma és a kutatások fókuszából, többek között ezért választottam vizsgálati terepként. Az interjúk alapján is látható, hogy a vidéki és fóvárosi színház között erőteljes kontraszt húzódik a karrier és az infrastrukturális lehetőségek szemszögéből. A színház mint szervezet múködését elsősorban a földrajzi helyzete határozza meg, utóbbi jelentős befolyást gyakorol a sikerérzetre és karrierpályára egyaránt. Interjúalanyaim válaszai is ezt támasztják alá.

„Itt vidéken adott, hogy csak a színházzal foglalkozzam, nem viszi el más a figyelmet, mint Pesten. De a szakma figyelme miránk nulla, mindentől meszsze vagyunk, nem figyelnek ránk. Fájó dolog, hogy a kritikusok sem jönnek el, 


\section{KÖZELKÉP}

kevésszer játszunk el egy darabot, amit Pesten 600-szor játszanak el. Pesten már a színház is túlpolitizált. Pedig a színház volt az egyetlen mentsvár, ott nem volt bal- meg jobboldal. Itt vidéken nem politizálunk a büfében." (61 éves színművésznő)

„Vidéki színháznak előnyei nem nagyon vannak. Kikerül a körforgásból. Pest ilyen szempontból egy külön ország. Kiesünk a figyelem fókuszából. Megszűntek a kritikák is... Azelőtt volt egy film-színház-kritikai lap és fizettek a kritikusnak, hogy jöjjenek vidékre. Ha a színház ma nem szervezi meg, hogy lejöjjön, akkor nem jön, mert drága. Kiesünk a figyelem fókuszából. Van egy pár esemény, amire odafigyelnek, de ez egy általános tendencia." (77 éves színművész)

„Vidéken több idő és alkalom van dolgozni, nem pénzhajhászás van. Nem nyúzzák szét a színészt szinkronnal satöbbi, persze ennek van hátránya, ugyanis a színészetből nem lehet megélni. Fizetéseink hagynak némi kivetnivalót maguk után. Fővárosi színészeknél próba kettőkor vége, rohannak máshova dolgozni. Vidéken föleg, ha van párja, nyugodtabb alkotási folyamathoz lehet hozzájutni." (43 éves színművész)

Az interjúalanyok válaszából érzékelhető, hogy bár kiemelik a vidéki színészlét előnyös oldalát, ami a nyugodtabb életritmusból, kisebb mértékű átpolitizáltságból adódik, ám a hátrányokat is megnevezik. Többek között, hogy a fővárosi színházi világhoz mérve nem kapnak elég szakmai figyelmet, ezért munkájuk, tehetségük csak egy szűkebb réteghez jut el. Sőt anyagi szempontból is hátrányosabb helyzetben vannak.

„Ami zavar, az a strukturális müködés: nekem nagyon furcsa Pest után azt látni, hogy vidéken egy darabot kevésszer játszunk el, tehát 25-30-szor lemegy; ez pocsékolás. Megérdemelnék, hogy máshol is többen lássák." (37 éves színmüvésznő)

A válaszadó szerint a népszínházi státuszból fakadóan széleskörű igényeket kielégíteni akaró repertoárnál fogva nincs lehetőség „kijátszani” egy-egy darabot, így ezt szakmai és anyagi szempontból is pazarlásként éli meg a vidéki színházban.

A vidéki és a fővárosi színészlét kontrasztja látványos, ezt az interjúalanyok mindegyike egyöntetűen alátámasztja. Legtöbbjük véleménye szerint a vidéki színészi élet számos előnnyel jár, ilyenek például a színházi társulat családias jellege, az elmélyült műhelymunkák, nyugodt alkotófolyamatok és a kollegiális bizalmi kapcsolatok megléte. Ugyanakkor számos problematikus szempontra is felhívják a figyelmet, amelyek a karrierépítést, szakmai sikert, anyagi megbecsültséget korlátozzák. 


\section{KÖZELKÉP}

Elmondásaik alapján nincs lehetőség szinkronmunkára, filmszereplésekre, hiányzik a minőségi szakmai kritika, távol vannak a színházi hatalmi centrumoktól és nem kapnak kellő figyelmet. Ezért véleményük szerint egyfajta aszimmetria, „vízfejűség” jellemző a gyakran „sznobsággal” vádolt pesti és a vidéki színházak összehasonlításában. Ahogy ez Barabási 2. sikertörvényénél is olvasható, a vidéki színházak háttérbe szorulása miatt sikerességük kevéssé mérhető a fővároshoz képest (reklám, kritika, figyelem, image), holott a vidéki és a budapesti múvészek teljesítménye, tehetsége nagy valószínűséggel nem különböző. Mindezek függvényében kijelenthető, hogy a népszínházi profil szimultán hordoz magában előnyt és hátrányt. A nemekre pedig látható, hogy a vidéki színészlét nemcsak a nők, de a férfiak helyzetére, sikerérzetére, karrierjére is egyaránt erőteljes hatással van.

\section{A színházi alrendszer mint a szervezet mezoszintje}

A szervezetek nemi szempontú vizsgálatai alapvetően a funkcionalizmusból nőtték ki magukat. Kutatásomban Parsons AGIL-sémáját alapul véve ismertetem és értelmezem a színházi világot mint sajátos alrendszert. Parsons a rendszerelméleti megközelítését először két munkájában a The Social System és a Toward a General Theory of Action címü munkáiban fejti ki. Ezen elméletét későbbi munkáiban az úgynevezett AGIL-sémával ${ }^{3}$ egészítette ki. Parsons szerint a modern társadalmak rendszerében a cselekvési rendszer négy alkotóelemből áll: társadalmi rendszer, kulturális rendszer, személyiségi rendszer és viselkedési rendszer (Somlai - Némedi 1988).

Ebben a kontextusban a vizsgált vidéki kőszínházak világát „,színházi alrendszernek" tekintem. A színház mint rendszer a szervezet egységes képének a megalkotására törekszik a külvilág felé, azonban a színházi alrendszer ennél jóval fragmentáltabban múködik. A színházi alrendszer funkcióihoz kapcsolódik a „külső gyártási folyamat” és a „belső üzemi működés” is. A külső gyártási folyamathoz sorolom az anyagi forrásokat, a humán erőforrást, a managementet és az image-et. Ehhez társul még a színház külvilág felé önmagáról alkotott víziója, hatalmi viszonyai és a külső társadalmi változásokhoz való alkalmazkodásának jellege. Ez a külső gyártási folyamat rokonkifejezés Barabási sikerértelmezésével ugyanis a megrendelői igények, a szervezeti kommunikáció során kap a színészi alkotómunka sikerességértékelést. A rendelkezésre álló szervezeti dokumentumok alapján a színház külsődleges gyártási folyamatához tartozik, hogy általában önkormányzati alapításúak és finanszírozásuk döntő többsége ebből a forrásból származik. Azonkívül bürokratikus, többszörösen hierarchikus szervezeti kultúrával bírnak. Szakmai missziójukban és víziójukban a népszínházi létből fakadóan széles körű igényeket szolgálnak ki, ezért

${ }^{3}$ Az AGIL-séma: adaptáció (A), célmegvalósítás (Goal Attainment), integráció (I) és struktúrafenntartás (Latent Pattern Maintenance). 


\section{KÖZELKÉP}

a klasszikus elvek meghatározóak, melyek időnként kiegészülnek kortárs, friss kezdeményezésekkel.

A belső működésben ott vannak a Bourdieu mezőelméletéhez kapcsolódó illúziók és habitusok. A színház belső üzeme fragmentált, hierarchikus hatalmi viszonyok között működő, szokások, normák, szabályok hálózzák be, szövik át. A külső és belső folyamatok harmóniáját nehéz kialakítani és ellentmondások merülnek fel, mivel egységes kisugárzással, de széttagolt belső működéssel kell reagálnia a külső környezetére. A hierarchikus hatalmi viszonyokból, a színházi rendszer és alrendszer strukturális problémáiból fakadóan beszélhetünk nemi egyenlőtlenségekről. Többek között a színésznő váltókori hátrányáról (drámairodalom szereparánytalanságai a nők és férfiak lehetőségeiben, életkorában; fiatal és idős női szerepek többsége, középkorú nők kevesebb lehetősége, férfiaknál fordítottan), a társadalmi nárcizmus következményeként a szépség abszolutizációjáról, a női vezetők (rendezőnők, igazgatónők) alacsony számáról és nehezített pályájáról.

\section{A színházi mező mint a szervezet makroszintje}

A színház belső működésének szociológiai igényű leírásához Bourdieu művészeti és irodalmi mezőelméletét veszem alapul. A színházi világ, mint minden más mező, sajátos jellemzőkkel bír, gondoljunk itt a bürokratikus szervezeti működésre, az objektíven és szubjektíven kialakított belső hierarchiákra, szoros kollegiális kapcsolatokra. Erre a mezőre olyan „erőtér”-ként tekintek, ami maga köré rendezi és beszívja a „közös illúzió”-val rendelkező benne élő színészeket és színésznőket. Ők identitásukban is azonosulnak a színházhoz tartozással, ezen belül egyénileg (habitus) viszonyulnak hozzá. A habitusokban vannak azonosságok (például jellemzően extrémebb, szenzitív személyiségek választják ezt a pályát), de jól elhatárolható különbségek is. Bourdieu A müvészet szabályai, az irodalmi mező genezise című művében írja le a mező, habitus és illúzió fogalmát, amelyeket magam is felhasználok vizsgálatomban. A színház világát olyan sajátos mezőként értelmezem, amelyben a „habitus" a színésznők, színészek általános attitűdjével, szakmai elhivatottságukkal, önkifejezés utáni vágyukkal, a színház iránti szakrális viszonyulásukkal egyenlő. Ebben a színházi mezőben találnak otthonra az alapjaiban hasonló habitussal rendelkező színésznők és színészek. A színházi mezőhöz kapcsolódással a mező normáit, működési elveit elfogadják, vagyis Bourdieu kifejezését használva az „illúziót” magukra öltik (Bourdieu 2013). A színházi világ kettős elvárásrendszert támaszt a színésznőkkel és színészekkel szemben, amely egyrészt a teátrumok sajátos belső múvészvilágából, másrészt a nemek közötti egyenlőtlenségek a színházi mezőre is jellemző „férfias” normarendszeréből eredeztethető, ami az egymást kizáró gondolkodásmódot jelenti: a színésznő egyszerre legyen teljesítményelvű, ambiciózus, férfias, eközben maradjon hagyományos értelemben véve nőies. 


\section{KÖZELKÉP}

A Barabási 4. törvényében leírtak némiképpen érvényesek lehetnek a színházi mező külsődleges működésére is, mivel a színházi társulat egy erős csapatmunkát, számos foglalkozási és művészeti ág találkozását jelenti, ahol a szakmai teljesítményre építve egységes kisugárzású image-et kell kommunikálnia önmagáról. Lehetőség szerint a kudarcok kerülésére, a jó összkép megtartására törekednek, és ennek érdekében a külsődleges sikerekre és a sztárkultuszra is építeniük kell. Így gyakorlatilag fennállhat annak lehetősége is, hogy az igazán nagy siker mindig arra az egy-két főre irányul, akik már korábban is külső sikereket könyvelhettek el, ugyanakkor mindig kitartó csapatmunka áll mögötte.

1. táblázat. A vidéki színház szerveződési szintjei

\begin{tabular}{|l|l|l|l|}
\hline Szint & Mikro & Mezo & Makro \\
\hline Szervezeti forma & Vidéki színház & Színházi alrendszer & Színházi mező \\
\hline & népszínházi elvárások & $\begin{array}{l}\text { külső megjelenés, } \\
\text { image }\end{array}$ & illúzió és habitus \\
\cline { 2 - 4 } & $\begin{array}{l}\text { klasszikus drámairo- } \\
\text { dalmi művek prioritása }\end{array}$ & $\begin{array}{l}\text { finanszírozási nehéz- } \\
\text { ségek }\end{array}$ & $\begin{array}{l}\text { kevés kortárs } \\
\text { reflexió }\end{array}$ \\
\cline { 2 - 4 } & $\begin{array}{l}\text { széleskörű nézői } \\
\text { igények }\end{array}$ & $\begin{array}{l}\text { külső kapcsolati } \\
\text { hálózat }\end{array}$ & $\begin{array}{l}\text { „férfias" múködési } \\
\text { folyamatok }\end{array}$ \\
\cline { 2 - 4 } & $\begin{array}{l}\text { bürokratikus színházi } \\
\text { struktúra }\end{array}$ & $\begin{array}{l}\text { „megrendelői” } \\
\text { igények }\end{array}$ & $\begin{array}{l}\text { kettős } \\
\text { normarendszer }\end{array}$ \\
\hline \multirow{2}{*}{ Konfliktus } & $\begin{array}{l}\text { nói és férfi } \\
\text { karrierkorlátok }\end{array}$ & múvészi korlátok & $\begin{array}{l}\text { (színész)női elő- } \\
\text { nyök és hátrányok }\end{array}$ \\
\hline
\end{tabular}

Forrás: Saját szerkesztés

Az 1. számú táblázat összefoglalja a fentebb kifejtett kőszínházi szerveződési szintek legfőbb attribútumait. A legkisebb szinttől haladunk a kiterjedtebb szerveződési szintek felé. A szintek egymásba kapcsolódva hatnak a színésznők siker- és karrierdefinícióira és egyenlőtlenségeire. A mikroszinthez kapcsolódnak a népszínházi elvárások, melyek a széleskörű nézői igények kielégítésére vonatkoznak, a klasszikus drámairodalmi művek szereparánytalanságai (melyek meghatározzák egy-egy előadás dramaturgiai szálát), ezen a szerveződési szinten a konfliktust a bürokratikus múködési módokban (merev, hierarchikus múködés és abból fakadó egyenlőtlenségek a nemek között) lehet megragadni. Már ezen a szinten láthatóak azok a működési elvek, melyek a színésznők és színészek közötti egyenlőtlenségeket okozzák. A kőszínházi struktúra mezoszintjéhez tartozik a külvilág felé mutatott image, a külvilággal kialakított kapcsolat, a színházi múködés finanszírozási módja és annak korlátai (megrendelői igények, műsorpolitika meghatározása). Ezen a szinten a megrendelói igények és a múvészi alkotófolyamat feszülnek egymásnak. 


\section{KÖZELKÉP}

A makroszintű szerveződési szinthez tartozik a színésznők és színészek színházhoz való személyes és szakmai viszonyulása, attitűdje (illúzió és habitus), a férfias működési folyamatok (teljesítményelvű, ambíciózus), és a kettős normarendszer is, amikor a férfias működési elvű szervezetben a színésznőktől és színészektől is ugyanazt a teljesítményt várják el, ugyanakkor a klasszikusan nőiesnek tulajdonított szerepeknek is meg kell felelniük. A színházi mező kettős elvárásrendszeréből is feszültség keletkezik, mely újabb női és férfi egyenlőtlenségeket okoz.

\section{Siker- és karrierdefiníciók nemek szerinti különbségei}

Az eddig leírtak alapján is látható, hogy a sikeresség megragadása nehéz feladatnak bizonyul. Ugyanis hozzátartozik a külső siker, amit a társadalom ruház fel értékekkel (vidéki vagy fővárosi színész, image, megrendelői elvárások, műsorpolitika, anyagi források), továbbá a belső elégedettség, amely az egyéni, szubjektív rangsorok alapján jön létre, benne van a karrier és a teljesítmény (kritika, nézői visszajelzés, kemény munka, kudarcélmények, újrakezdések), valamint a színházi közegben felértékelődő tehetség kérdése. A vidéki kőszínházak szervezeti működése konfliktusos viszonyban áll a siker és karrier jelenségével, amelyet alanyaim válaszai is alátámasztanak. Az alábbiakban külön vizsgálom a színésznők és színészek siker-, karrierfogalmait, az értékekre vonatkozó szubjektív rangsorait, ezáltal kimutathatóvá válnak a két nem között meglévő azonosságok és eltérések is.

\section{a) Színmúvésznők sikerdefiníciója}

„Szerintem ez is életkor kérdése. Kezdőként azt gondolod, hogy filmek, karrier, Oscar-díj, amerikai karrier. Összes magyar díj, imádnak, egy leheletemért milliókat fizetnek, felismernek. De ez változik, amit 20 évesen gondoltam a sikerről, az most köszönőviszonyban sincs ezzel. Én ma már a belső fejlődést, a lelki nyugalmat nevezem sikernek."4 (51 éves színművésznő)

A válaszoló az életkor kérdésére irányítja a figyelmet, amely értelmezése szerint jelentős befolyással bír a színésznői pályájára és a sikerre. Válaszaiból úgy tűnik, mintha az életkor múlásával lenne magyarázható a kevesebb siker vagy a sikerről való másként gondolkodás. Természetes folyamatként értelmezhető, hogy a személyiség fejlődésével és változásával eltérően definiálja a sikert, ugyanakkor itt mégiscsak megjelenik egyfajta színésznői hátrány, például amikor egy színésznő 40 éves

\footnotetext{
${ }^{4}$ Az interjúalanyokról a kutatás anonimitási elvének betartása érdekében többletinformációt nem adok meg.
} 


\section{KÖZELKÉP}

kor felett kevesebb főszerepet kap, mint férfi kollégái, amikor már nem olyan fiatal, hogy eljátszhassa a drámairodalom szép és fiatal hősnőit, de még nem is olyan idős, hogy a dada vagy akármely érettebb női szerepre alkalmas legyen. Ezért ez a kijelentés kompenzációs magyarázatként is értelmezhető. Ez Lasch $A z$ önimádat társadalma című könyvében kifejtett nézetével állítható párhuzamba, miszerint az 1970-es évektől egészségtelen módon felértékelődni látszik a fiatalság, a test esztétikuma, vagyis az öregedés a külső megítélésre és a sikerességre is negatív hatással van. Ez különösen igazzá válhat a színpadon reflektorfényben álló színésznő esetében. Már a fenti interjúrészletből is láthatóvá válik, hogy a szubjektív változók bevezetésével nem csupán az anyagi és a jövedelmi helyzeten keresztül mérhetjük az emberi elégedettséget, sikerérzeteket, hanem jelentős többletinformációkat is kaphatunk. Az interjúalanyok egy része az objektíven mérhető faktorok közé sorolja a magas fizetést, a népszerűséget.

„Olyan igazi siker? Most már az igazi sikert a gyerekeim által érem el. Régen, a gyerek elótt, rengeteg sikerem volt. A siker elégedettség. Ha meg tudom ôrizni a lelki nyugalmamat, az számomra siker és a hosszú élet titka. Ezen a pályán hihetetlen stressznek vagyunk kitéve állandóan. Már csak azzal, hogy kilépsz a színpadra, jó-e a sminkem, ruhám, bakizom-e." (41 éves színművésznő)

Ebben a válaszban is előkerülnek a család és a gyereknevelés kérdései. A belső siker, vagyis a "teljesítményorientáció” itt is felértékelődik a külső sikerrel szemben. Előkerül az életkor faktora, amit fiatalkori külső sikerként élt meg. Az idős vagy érett korban lévő színésznők esetében a teljesítményorientáltság kerül előtérbe a külső sikervággyal szemben.

„Számomra a sikeresség az, ha elégedett vagyok azzal, amit csináltam, illetve a hozzám közel álló megmondó emberek elismernek. Ha egy munka alapján hívnak el dolgozni, az nekem sikeresség. Van egy másfajta siker, azt a celebekkel hozom össze: sokat keresek, írnak rólam az újságban, megismernek. A szakma elismerése fontos, a celebeket nem ismerik el annyira." (34 éves színművésznő)

A válaszadó szerint a sikeresség szinonimája lehet az elégedettség és a külső sikerhez tartozó „celebség”, ami sok esetben a siker teljesítmény nélküli hajhászása. A belső sikerhez kapcsolja a teljesítményt, a kemény munkát és saját rangsorában ezek elsődleges szempontként szerepelnek csakúgy, mint Deaton-Kahnemann és Barabási megállapításában láthattuk. 


\section{KÖZELKÉP}

„Nehéz kérdés, mi is a siker, mert vannak olyan előadások, amik borítékolják, hogy közönségsiker, és van egy másik jellegü darab, amin rengeteget dolgoztok, van egy vezérelve és az meg kevésbé.” (26 éves színművésznő)

A színészek belső élménye (szubjektív siker) és a közönség visszajelzése (külső/ objektív siker) gyakran nincsenek egymással átfedésben. Barabási siker, teljesítmény és hálózatok megfigyelésére vonatkozó kutatása is hasonló eredményekre jutott. A színészek számára szakmai és kollegiális értelemben fontos munkát, kreativitást jelent egy-egy színdarab, de előfordulhat, hogy a külső megítélés mégsem ismeri fel ezeket az értékeket. A művészi alkotómunka megítélése, mérése ebben az esetben is akadályba ütközik.

„Siker? Órákban, teljesítményben a müvészetet nem lehet mérni: láthatatlan mérő van mindenkiben. Az valahol siker, hogy jól végzem a munkámat. Elégedett vagyok, nincs hiányérzetem vagy nem olyan nagy. Nekem ez a siker." (41 éves színművésznő)

A színésznő véleménye szerint az alkotómunkát és a valódi teljesítményt nem lehet összekapcsolni azzal, ahogy azt külső szemmel megítélik, mégis úgy tűnik, hogy ebben van némi pszichológiai magyarázat is, ami „felmenti” őt a sikertől való függéstől, így értelmezése szerint egy valódi művész számára kizárólag a belső elégedettsége adhat, illetve kell, hogy adjon sikerélményt.

„Az ember megtisztul egy próbafolyamat során. Mit értettem meg a világról, Istenrôl, helyzetekrôl. És ott a közönséggel való találkozás, legyen az felnőtt vagy gyerek. És amikor jönnek utána az emberek, visszajeleznek, hogy sírtak és megtisztultak, na ez a szociális munka, én akkor este szociális munkát végeztem. Most nagyon dühös vagyok ugyanakkor a szakmámra, mert két oldalra szakadt, mint a politika is. Tulajdonképpen a szakma nem szól másról, csak a politikáról. Most csak a közönség visszajelzésére számíthatok, mert sem kritikusok, sem fesztiválok nem reálisak, így a sikert a közönségtől tudhatom meg." (29 éves színművésznő)

Ehhez a belső elégedettséghez hozzátartozik a nevelés és a katarzis. Szintén utal a díjak, jutalmak átpolitizáltságára (külső sikerítéletek) s ezáltal átláthatatlanságára is. Számára sem jelent abszolút sikert az, ha díjat kap, mert nincs tisztában azzal, hogy mennyire hiteles ez szakmai szemszögből nézve. Ebből is kitűnik, hogy a belső (szubjektív sikerérzés) siker és a külső siker (a díjakban mérhető elismertség) konfliktusban állnak egymással. A belső sikeréhez, elégedettségéhez legtöbbet a közönség visszajelzése ad számára. Esetében is a teljesítményalapú karrier a mérvadó. 


\section{KÖZELKÉP}

„A karrierre lehet mondani, hogy mindenkinek mást jelent, mindenki máshogy határozza meg. Nyilván van egy kitüzött cél a munkájában, amit el szeretne érni és akkor elmondhatja, hogy sikeres utat futott be. Én ettöl a fogalomtól távol tartom magamat picit, mert engem sosem az mozgatott, hogy a külsó számára érjek el karriert. Nekem ez a karrier fogalma ilyen külsődleges dolog, amit a társadalom fogalmaz meg, lehet, ami nekem karrier, az másnak nem az. Az együttmüködésen alapuló létezést tartom fontosnak. Ami a sikert illeti, mindenképpen fontos nekünk a visszajelzés, mert nem önmagunknak és önmagunkért csináljuk, amit csinálunk, hanem hogy hassunk, azért, hogy mindenféle érzéseket ébresszünk azokban, akiknek csináljuk ezt. Belsô iránytün vagy mércén múlik, hogy én magamban ezt hova teszem. Kell az emberi és szakmai minőség is." (58 éves színművésznő)

Érzékelhető a színésznő külső siker fogalommal szembeni konfliktusos attitúdje. Kiemeli, hogy a siker számára az emberi és szakmai minőségek összefonódásából adódik, ezért neki elsősorban a tartós munkával elért, akár kudarcokkal teli, valódi teljesítményalapú karrier a fontos. A külső sikertől, népszerűségektől, celebritástól távol tartotta magát pályája során.

\section{b) Színmúvészek sikerdefiníciója}

„Én magam a sikert úgy fogalmazom meg, hogy ha elfelejtem a szót, hogy siker. Vannak olyan munkálatok, amikor ez teljesen huszadrangú. Ha mi színészek szeretjük a darabot játszani, ha jó légkörben tudunk dolgozni, felkészülni és a közönség elé tálalni, az észrevétlenül siker. Színházi zsargonban a bukás nem foglalkoztat. Mindig féltem az olyan kollégáktól, akik vérremenően sikerorientáltak. A karrier? Én valami olyasmit gondolok, hogy ha három év alatt vannak olyan munkafázisaim, amiben jó lenni, az nagyon jó, de nem tudom ez kapcsolódik-e a karrierhez. Erről talán a fövárosi színészeket kellene megkérdezni, nekik ez ott borzasztóan fontos." (56 éves színmüvész)

A színész elsődlegesnek a jó kollegiális légkört tartja, illetve a jó színházi produkcióban való munkálkodást. A teljesítményalapú karrier számára is fontos. A külső karrierhez való viszonya konfliktusos, ehhez a fogalomhoz ő a fővárosi színészeket társítja, valamint egy gőgösebb munkamorált, amely a kisebb sikereket nem értékeli kellőképpen.

„Siker az nyilván többlépcsős dolog. Elsősorban önmagammal való harcok legyőzése az siker. Éreztem már olyat, hogy ünnepeltek, pedig én azt éreztem, hogy ez nem az, szóval ez érdekes kérdés. A karrier mennyire érdekel és 


\section{KÖZELKÉP}

mennyire szempont... fontos, hogy legyen, de ki adja például a díjat, az megint érdekes. Ma már az a karrier, aki szerepelt filmben. Azt nem mondom, hogy nem érdekel a karrier, de ha nagyon érdekelne, már nem itt lennék vidéken, hanem hajtanám a casting ügynökségeket. Itt is emberek élnek és megérdemlik, hogy jót kapjanak. Talán a legnagyobb siker, ha az ember tud boldog életet élni, mindegy, hogy mi van. Aki rendben van magával, az megoldja, az siker." (34 éves színművész)

Megerősíti azt, hogy a belső elégedettség, tartósság és a belső küzdelem jelentik a valós sikereket az ember életében, amelyek disszonáns viszonyban lehetnek a külső sikerrel. A szubjektivitás itt is felértékelődik, a karrierhátrányokat a vidékiséggel kapcsolja össze. Láthatóan kevésbé konfliktusos a viszonya a külsődleges sikerrel, mint a színésznők esetében, a teljesítmény alapú karrier azonban számára is elsődleges.

„A siker az belülrôl nézve csak egy állomás. Szerintem úgy zajlik le az emberben, hogy hogyan tovább, hogy erre rászolgáljon az ember vagy teljesítsen még többet. Egy színész nem attól lesz jobb, ha nagyon sokat próbál. Sokat látunk a szakmában, aki sikeres, pedig nem olyan tehetséges a szakma szerint. Mondjuk úgy, hogy helyezkedés vagy önmenedzsment kérdése? Piacorientáltság van, ki adja el legjobban önmagát." (37 éves színművész)

Itt is előjön a pillanatnyi siker és a tartós, teljesítményalapú karrier kérdése. A külső sikert átláthatatlan folyamatként írja le, melynek része az önmenedzselés, eladhatóság, a piacorientáltság. A gyors siker nála is negatív kicsengésű, ahogy fentebb mindenkinél jellemző volt. Ez is részben hasonlít a színésznők által adott válaszra, miszerint a művészi sikert nem egyszerű megmérni, azonban a férfiak az okát külsődleges tényezőkkel magyarázzák.

„Sikeres lehetek önmagam, a közönség és a szakma számára. Önbizalom kérdése, hogy mi az, ami kielégíti az embert és még mire vágyna. Fontos az, amit a közönségről látok. Szakmában meg már írtak rólam mindenfélét. Én jól élem meg a sikert, nagyon szeretem, de lehet függni tôle nagyon. Emeli a tétet, de szükségszerü a visszajelzés." (37 éves színmüvész)

A válaszoló megélte már a külső sikert, kapott negatív és pozitív kritikai visszajelzéseket is. A színész többször tapasztalta a külső sikert, amit általában jó dolognak tart és még többre sarkallja. Tehát az ő viszonya nem olyan ambivalens ezzel, mint a vizsgált színésznőnek. Természetesen ezt is két irányból érdemes megközelíteni: egyfelől, hogy lehet a siker megélésének személyiségbeli vonatkozása, másfelől 


\section{KÖZELKÉP}

az eltérő attitűdnek lehetnek nemi okai is, melynek hátterében a strukturális hátrányok, tradicionális, hierarchikus viszonyok állnak.

„A sikerre vannak első körös válaszok: díjakat kap az ember, fószerepek sorát játssza el, filmeket forgat. Ezek összeadódnak, ezekben lehet mérni a sikert. Én kevésbé vagyok sikeres. Nem kapok díjat, nem forgatok, nem hívnak más színházak. Sokszor azt érzem, hogy mások nálam jobban érvényesülnek. $\mathrm{Ha}$ valaki nem jobb és mégis több lehetöséget kap vagy egyenlötlen a küzdelem, az belső konfliktust okoz. Általában a színház vezetését okolom minden helyzetben, mert azt gondolom, hogy övéké a döntési lehetöség ezer ügyben. És ha valaki elörébb tart kevesebb munkával." (40 éves színmúvész)

Az interjúalany világosan megfogalmazza, mit jelent a külső siker (érvényesülés, szinkron, népszerúség) és mit jelenthet annak elmaradása, melyet elsősorban külsődleges okokkal magyaráz. Ugyancsak felhívja a figyelmet a külső, gyorsan megszerzett sikeresség és a tartós, teljesítményalapú karrier konfliktusára. Előbbit a felszínes értékítéletekkel hozza kapcsolatba. Alapvetően tehát a férfi színészeknél is elsődlegesen fontos a teljesítmény alapú karrier, ugyanakkor a külső sikerrel szemben sokkal kevésbé konfliktusos a viszonyuk, mint a színésznőnek.

2. táblázat. Siker- és karriermátrix modellje

\begin{tabular}{|c|c|c|c|}
\hline & & \multicolumn{2}{|c|}{ Időbelisége } \\
\hline & & $\begin{array}{c}\text { Pillanatnyi } \\
-\end{array}$ & $\begin{array}{c}\text { Tartós } \\
+\end{array}$ \\
\hline \multirow{2}{*}{ Iránya } & $\begin{array}{l}\text { Objektív (társadalmi } \\
\text { jutalmak és büntetések) }\end{array}$ & $\begin{array}{l}\text { külső siker/ } \\
\text { sztárság }\end{array}$ & $\begin{array}{l}\text { karrier/ } \\
\text { teljesítmény }\end{array}$ \\
\hline & $\begin{array}{l}\text { Szubjektív (érzések, } \\
\text { mentális állapotok) }\end{array}$ & boldogság & élettel való elégedettség \\
\hline
\end{tabular}

Forrás: Saját szerkesztés

Ez a táblázat azokat a tipológiákat foglalja, sűríti össze, melyeket az interjúalanyok válaszából vontam le. A „mínusz” jelzés azt jelenti, hogy a siker eléréséhez a kudarc kockázata nem áll fenn vagy nem jelentős, a „plusz” jelzés viszont a kudarc, küzdelem magas kockázatát jelzi. A sikerrel és a karrierrel kapcsolatos vélekedések iránya egyfelől lehet objektív, ahol „[a] jutalom arányos a tágan értelmezett érdemmel” (Parsons 2010: 32). Az objektív karrier „pillanatnyiságát” két típusra bontom, az (1) egyik a külső siker, ami a jó szakmai kritikában, interjúban, a nézők által kedvelt karakterek esetén jelenik meg, tehát egyfajta külsődleges jutalmat jelent, a (2) másik kategória a sztárság, amit a „celebségben”, a gyorsan jött hírnévben, ismertségben, „felkapottságban” határoztak meg a válaszadók. Az „objektív-pillanat- 


\section{KÖZELKÉP}

nyi” kategóriában a kudarccal való megküzdésnek a kockázata alacsony, vagy nincs. A „tartós siker” kategóriáját szintén két csoportra bontottam, ahol az egyik a karriert, a színész elnyert státuszát, pozícióját, szakmai tekintélyét jelenti, míg a másik a teljesítményt, ami a szakmai értékességet, a kemény munkát foglalja magában. Ez utóbbi az „objektív-tartós” típus, melyben a kudarccal való találkozás és megküzdés jelentős mértékű.

A szubjektív irány esetében, egyfelől a pillanatnyi érzéseket, mentális állapotokat jelenti, ez lesz a boldogság, másfelől egy belső, tartós állapot, amely az élettel való elégedettséget jelképezi. A pillanatnyi boldogság állapotába az aktuális öröm- vagy szomorúságérzetek tartoznak bele, míg az élettel való elégedettségbe a tartósan pozitív mentális állapot. Alább látható, hogy a színésznők és színészek válaszaira lebontva ez mit jelent kulcsszavakkal illusztrálva.

3. táblázat. Színésznők siker- és karrierasszociációi

\begin{tabular}{|c|c|c|c|}
\hline & \multicolumn{2}{|c|}{ Időbelisége } \\
\hline & & $\begin{array}{c}\text { Pillanatnyi } \\
-\end{array}$ & $\begin{array}{c}\text { Tartós } \\
+\end{array}$ \\
\hline \multirow[b]{2}{*}{ Iránya } & Objektív & $\begin{array}{l}\text { jó szakmai visszajelzés, kritika, } \\
\text { interjú, életkor, díjak / } \\
\text { celebség, népszerűség, „csapból } \\
\text { is ő folyik” }\end{array}$ & $\begin{array}{l}\text { elnyert státusz, pozíció, szakmai } \\
\text { tekintély, elismerés / } \\
\text { szakmai minőség, értékesség, } \\
\text { nézői szeretet }\end{array}$ \\
\hline & Szubjektív & $\begin{array}{l}\text { érzet, hatáskeltés, katarzis, } \\
\text { feloldódás az aktuális } \\
\text { szerepben, szenvedés hiánya }\end{array}$ & $\begin{array}{l}\text { belső fejlődés, lelki nyugalom, } \\
\text { nevelés, hasznosságérzet, } \\
\text { elégedettség, boldogság, emberi } \\
\text { minőség, határok átlépése, flow, } \\
\text { anyaság, gyermekek, családi } \\
\text { harmónia, szeretet kapcsolatok, } \\
\text { megküzdési stratégiák }\end{array}$ \\
\hline
\end{tabular}

Forrás: Saját szerkesztés

A színésznők válaszai alapján az „objektív-pillanatnyi” tipológiához számos fogalom társítható, melyek elsősorban a gyorsan, nem megérdemelten szerzett népszerűséget jelentik (celebség, népszerűség, csapból is ő folyik), és a jutalmak átpolitizáltságával vannak kapcsolatban. Művi, külsődleges fogalomnak tartják ezt a sikertípust, ezért a legtöbben elhatárolódnak tőle. Ugyanakkor egyes interjúalanyok szerint, olykor szakmájuk részének kell tekinteniük és tud jóleső is lenni. Az „objektív-tartós" tipológiába az interjúk alapján olyan kifejezéseket soroltam, mint a kemény munkát, hiteles szakmai visszajelzést, valódi elismerést, a közönséggel való jó légkört, viszonyt. A „szubjektív-pillanatnyi” kategóriához a válaszok alapján már azokat a fogalmakat soroltam, amelyek kapcsolatban állnak a színészi játék által kifejtett hatással, katarzissal, a szerepben való feloldódással. Ezenfelül ugyanúgy ide 


\section{KÖZELKÉP}

tartozik a belső lelki fejlődés, a kitartó önfejlesztés, a hasznosságérzet, lelki egyensúly elérése és megtartása, flow, anyaszerep fontossága. Minden olyan fogalom ide sorolható, amely a belső komfortérzethez társul. A színésznők legtöbben ezeket az értékeket tartották fontosnak a sikerrel kapcsolatban. A többi értéktől sem határolódnak el, de megfigyelhető, hogy a külső karrierrel, tehát az „objektív-pillanatnyi” és az „objektív-tartós” tipológiába sorolt értékekkel szemben ellentmondásos a viszonyuk. Ezenfelül a színésznők többségénél megjelenik még az életkor kérdése, mely jelentősen (többnyire hátrányosan) befolyásolja a siker és karrier kérdését. A színésznők számára a hasznosságérzet, az élethosszig tartó önfejlesztés fontos, és magasan értékelik a lelki egyensúlyt is.

\section{4. táblázat. Színészek siker- és karrierasszociációi}

\begin{tabular}{|c|l|l|l|}
\hline \multicolumn{2}{|l|}{} & \multicolumn{2}{c|}{ Időbelisége } \\
\cline { 3 - 4 } & \multirow{2}{*}{$\begin{array}{c}\text { Pillanatnyi } \\
\text { Iránya }\end{array}$} & $\begin{array}{l}\text { Oscar-díj, fővárosi színészlét, } \\
\text { önmenedzselés, vérremenő } \\
\text { sikerorientáció, érvényesülés, } \\
\text { sikerhajhászás, politika, díjak }\end{array}$ & $\begin{array}{c}\text { Tartós } \\
+\end{array}$ \\
\cline { 2 - 4 } & \multirow{2}{*}{ Objektív } & teljesítmény, szakmai elismerés \\
Szubjektív & $\begin{array}{l}\text { jó kollegiális légkör, aktuális } \\
\text { darabot szeretik játszani }\end{array}$ & $\begin{array}{l}\text { önmaga legyőzése, önbizalom, } \\
\text { boldogság, rendben van } \\
\text { magával, nevelés, tanítás, } \\
\text { görcsöktől megszabadulás }\end{array}$ \\
\hline
\end{tabular}

Forrás: Saját szerkesztés

A színészek esetében az „objektív-pillanatnyi” tipológiához erőteljesebb, intenzívebb negatív konnotációjú fogalmak párosíthatók. Ami megfigyelhető, hogy a színésznőkhöz hasonlóan a díjak átpolitizáltságát, a gyorsan jött külsőségeket, népszerűséget ők is a pillanatnyi sikerhez párosítják, és ezt több férfi interjúalany elsősorban a fóvárosi színészléttel párosítja. Az önreklám, a „nyomulás”, az érvényesülés fogalmai mind ide sorolhatóak. Amit fontos kiemelni, hogy a férfiak az életkor kérdését egyáltalán nem említették az interjúk során. Itt visszaköszönhet a drámairodalmi örökségből és a szervezeti megrögzöttségekből eredő bizonyos fokú szakmai előnyük. Általában ők is a kemény munkával elért szakmai minőséget tartják a legfontosabbnak, azonban megemlítik még a teljesítmény és önbizalom szükségességét is. A színésznők közül többen kiemelték, hogy a művészetet nem lehet teljesítményben mérni, a színészek pedig a tartós, objektív karriert alapvetően teljesítményfüggőnek írták le. A „szubjektív-pillanatnyi” kategóriába a férfiak esetében is ugyanazok az értékek sorolhatóak be, mint a nőknél; a jó kollegiális légkört és az aktuális produkción munkálkodás örömérzeteit. A „szubjektív-tartós” kategóriában pedig a boldogság el- 


\section{KÖZELKÉP}

érésének célja, a kemény mentális munka szerepeltek. A színészek érdekes módon nem említették a család vagy a gyermeknevelés kérdését. Ezen a ponton eltérés figyelhető meg a nemek között. Bár a színészek számára is a legutóbbi „szubjektív-tartós" kategória tartalma a legfontosabb, de a siker és karrier definiálása során nem érzékelhető a nőknél tapasztalható feszültség. A férfiaknál fellelhetőek a hagyományos karrierfogalom elemei is, mint a teljesítmény, az eredmények, a ranglétrán való vertikális előrejutás.

5. táblázat. Színésznők és színészek tipológia/habitus az asszociációk alapján

\begin{tabular}{|l|l|l|l|}
\hline \multirow{2}{*}{} & \multicolumn{2}{|c|}{ Időbelisége } \\
\cline { 3 - 4 } & \multicolumn{2}{|c|}{ Pillanatnyi } & \multicolumn{1}{c|}{$\begin{array}{c}\text { Tartós } \\
+\end{array}$} \\
\hline \multirow{2}{*}{ Iránya } & Objektív & „celebritás”, „celeb” & $\begin{array}{l}\text { "színész-óriás”, „színésznő- } \\
\text { óriás” }\end{array}$ \\
\cline { 2 - 4 } & Szubjektív & "tragika-komika”, „a bohém” & „élet hőse”, „élet hősnője” \\
\hline
\end{tabular}

Forrás: Saját szerkesztés

Ebben a táblázatban mindkét nem definíciói által egy-egy színészi típust jelölök, melyek a kategóriák minőségeit tükrözik vissza.

Objektív + Pillanatnyi sikert birtokló színész tipológia = „celeb”, „celebritás”.

Objektív + Tartós karrierrel rendelkező művész = „színész- és színésznő-óriás”.

Szubjektív + Pillanatnyi boldogságot átélő színésznő, színész = „tragika-komika”, „a bohém”.

Szubjektív + Tartós élettel való elégedettségre törekvő színésznő, színész = „az élet höse”, „hösnője”.

A megkérdezett interjúalanyok legfőbb törekvése és elégedettsége abból származik, ha a színész tipológia alapján az „élet hősei” és az „élet hősnői” lehetnek, vagyis a „szubjektív-tartós” sikert tekintik a legfontosabb kategóriának. Ugyanakkor egyértelműen vágynak a „színész- és színésznő-óriás” szerepkörére is. A „tragika-komika” és „a bohém” szerepköreit megélik aktuális örömeikben, érzelmi hullámzásaikban. A „celebség”, a „celebritás” negatív konnotációjú szerepkör, kevesen vágyódnak utána, szakmai hiteltelenséget kapcsolnak hozzá. „Egy olyan társadalomban, amelyben a sikervágy mögül kiszivattyúztak minden önmagán túlmutató tartalmat, kizárólag a mások teljesítménye lehet a saját teljesítmény mércéje. Nem dicsőségre vágynak, hanem a hírnév csillogására, izgalmára. Társadalmunkban a sikert a nyilvánosság iktatja törvénybe." (Lasch 1996:103) 


\section{KÖZELKÉP}

\section{Összegzés}

A tanulmányban arra a kérdésre kerestem a választ, hogy kimutathatóak-e különbségek abban, ahogy a színésznők és színészek definiálják karrierjüket, sikereiket? Mikor és mitől elégedettek a sikereikkel? Mit jelent a vidéki színház színészeinek sikere?

A vidéki kőszínházi szervezet nyújtott értelmezési keretet a színésznők és színészek közötti egyenlőtlenségek leírásához. A szervezeti struktúrát mikro-, mezo- és makroszinten értelmeztem, jelezve, hogy az interjúalanyok siker- és karrierfogalmára hatással vannak a szerveződési szintek és az általuk generált feszültségek. Ezek közé tartozik a történelmi örökségként fennmaradó merev, bürokratikus színházi intézményi működés, a drámairodalmi szereparánytalanságok, a kevés kortárs reflexió, a színházi dokumentáció fejlődésének lassúsága. Azonkívül a finanszírozó oldaláról érkező megrendelői igények és a művészi alkotómunka között fellépő feszültség, valamint a kettős normarendszer elvárásai. A kőszínházi struktúra felépítéséből számos feszültség keletkezik, melyek hatással vannak a színésznők és színészek siker- és karrierdefinícióira.

A kutatás eredményei azt mutatják, hogy mindkét nem három irányból közelíti meg a sikert: (1) belső mérce, (2) tágan értelmezett szakma, (3) közönség.

A színésznők és a színészek döntő többségének válasza alapján megállapítható, hogy a siker fogalmában alapvetően a szubjektív elégedettség és a teljesítményalapú karrierorientáció felértékelődése figyelhető meg. Itt érdemes kiemelni, hogy ez a habitus döntő többségben azonban érett korú, tapasztalt, akár már gyermeket szült színésznőknél vezető kategória, ahol nem kizárólag a színházi hivatásukból nyernek tartós elégedettséget. Ami a színésznők és színészek számára egyaránt végső cél: a „színésznő-/színészóriás” és az „élet hősnője/élet hőse” tipológiával való azonosulás lehetősége, ugyanakkor a férfiak nem zárkóznak el a „pillanatnyi-objektív” sikertől sem olyan élesen, nekik a karrierfogalommal komfortosabb attitűdjük van. A férfi színészek habitusában jobban előtérbe kerül a pillanatnyi siker utáni vágyakozás, vagy legalábbis a nőkhöz képest nyíltabban mernek beszélni róla.

Az interjúalanyok válaszai alapján színésznői és színészi tipológiákat alkottam. A nők és a férfiak többsége az „élet hősei” és az „élet hősnői” szeretnének lenni, vagyis a „szubjektív-tartós” sikert tekintik a legfontosabbnak. Közben vágynak a nagyívű karrierpályát befutó „színész- és színésznő-óriás” szerepkörére is. A „tragika-komika” és „a bohém” szerepköreit megélik aktuális örömeikben, a hétköznapokban. A „celebség” alacsony presztízsű szerepkör, kevesen vágynak rá.

A színésznőknek és a színészeknek egyaránt van lehetőségük arra, hogy sikeresek legyenek, hogy karriert építsenek. A köztük lévő eltérések, más hangsúlyok elsősorban a tradicionális, hierarchikus rendszer örökségei, a színházi szervezeti működés elvárásrendszere határozza meg. A színésznők a szubjektív változók szemszögéből nézve, vagyis életlehetőségeikben, életükkel való elégedettségben, egyformán emancipáltak a színész kollégáikkal. Ennek ellenére a színházi mező férfias 


\section{KÖZELKÉP}

elvárásrendszerének való megfelelés szempontjából hátrányban vannak, ezért habitusaikban az tükröződik, hogy a színházon kívül is van élet számukra, sikereik azokról a területekről is származnak. A színésznői hátrányok, mint például a drámairodalmi aránytalanságok, a változókori krízis erős hatással vannak a karrierjükre és sikerérzeteikre, s ennek kompenzálására „magánidentitásokat” hoznak létre (tanítás, karitatív tevékenység, család, gyermeknevelés, más művészeti ágakban elmerülés). Az interjúkból kirajzolódik, hogy a színházi világban dolgozó színésznők és színészek siker- és karrieraspirációi közel azonosak a pályájuk kezdetén. Az életkorral, az elvárásrendszernek megfeleléssel módosulhatnak ezek a kezdeti elvárások, melyek indikátorok karrierakadályaik felismerésében.

\section{Irodalom}

Balestra, C. - Boarini, R. - Tosetto, E. (2018): What matters most to people? Evidence from OECD better life index useres responses. https://ideas.repec.org/a/spr/ soinre/v136y2018i3d10.1007_s11205-016-1538-4.html (Letöltve: 2020. 02. 17.)

Barabási, A. L. (2018): A képlet - A siker egyetemes törvényei. Libri Kiadó, Budapest

Bourdieu, P. (2013): A múvészeti szabályai. Az irodalmi mező genezise és struktúrája. Budapesti Kommunikációs és Üzleti Fơiskola, Budapest

Deaton, A. (2013): A nagy szökés. Egészség, gazdaság, és az egyenlötlenségek eredete. Corvina Kft. Kiadó, Budapest

Kahneman, D. - Deaton, A. (2010): High income improves evaluation of life but not emotional well-being. https://www.researchgate.net/publication/46169956_ High_Income_Improves_Evaluation_of_Life_But_Not_Emotional_Well-Being (Letöltve: 2020. 02. 17.) https://doi.org/10.1073/pnas.1011492107

Lasch, C. (1996): Az önimádat társadalma. Európa Könyvkiadó, Budapest.

OECD (2017): Better Life Index - Country Reports. https://www.oecd.org > BLI2013Country-Notes (Letöltve: 2020. 02. 17.)

Parsons, T. (2010): A társadalmi rétegződés elméletének átdolgozott analitikus megközelítése. In: Angelusz R. - Éber M. - Gecser O. (szerk.): Társadalmi rétegződés olvasókönyv. TÁMOP 2010-201. 23-50. https://regi.tankonyvtar.hu/hu/tartalom/tamop425/0010_2A_19_Tarsadalmi_retegzodes_olvasokonyv_szerk_Gecser_0tto/0010_2A_19_Tarsadalmi_retegzodes_olvasokonyv_szerk_Gecser_Otto. pdf (Letöltve: 2020. 11. 18.)

Somlai P. - Némedi D. (1988): Talcott Parsons a társadalmi rendszerról. ELTE Szociológia Intézet és Továbbképző Központ, Szociológiai Füzetek, Budapest

Váriné Sz. I. - Solymosi Zs. (1999): A siker lélektana. Új Mandátum Könyvkiadó, Budapest 